\title{
Cristianos, maoístas y peronistas. Elementos para una historia comparada de Açao Popular en Brasil y Montoneros en la Argentina
}

Esteban Javier Campos*

Resumen: El propósito de este artículo es analizar las militancias políticas de Açao Popular y Montoneros, a partir del método comparativo propuesto por Marc Bloch en su ya clásico artículo Para una historia comparada de las sociedades europeas. Siguiendo esa línea de pesquisa, estudiaremos las trayectorias de ambas organizaciones comparando sus orígenes en el catolicismo renovador, su acercamiento a posiciones socialistas y la diferenciación de sus elecciones políticas, en Montoneros hacia el peronismo y en Açao Popular hacia el maoísmo. A partir de esta aproximación podremos plantear hipótesis de trabajo sobre la especificidad de los procesos políticos a escala nacional, en particular la fortaleza o la debilidad de las formaciones políticas izquierdistas y populistas en ambos países, así como los cruces y desencuentros entre ambas tradiciones. Para el trabajo se relevó bibliografía general sobre guerrilla e izquierdas en Argentina y Brasil, así como específica sobre Açao Popular, Montoneros, la cuestión de la radicalización político-religiosa y el método de la historia comparada. Por otro lado, se analizaron una serie de documentos pertenecientes a las dos organizaciones.

Palabras clave: Açao Popular. Montoneros. Maoísmo. Peronismo. Método comparative.

* Doutor em História pela Universidad de Buenos Aires - UBA. Investigador Assistente do Consejo Nacional de Investigaciones cientificas y Técnicas (CONICVET). Membro do Grupo de Trabalho Clasco "Violencia y Politica. Um análisis de las militancias de izquierda em América Latina”. E-mail: estebancampos1977@gmail.com.

Anos 90, Porto Alegre, v. 23, n. 43, p. 93-127, jul. 2016 


\section{Introducción}

Nuestra organización es una unión de hombres profundamente argentinos y peronistas, dispuestos a pelear con las armas en la mano por la toma del poder para Perón y para su pueblo y la construcción de una Argentina Justa, Libre y Soberana [...] Nuestra doctrina es la doctrina justicialista, de inspiración cristiana y nacional.

Comunicado n. 5 de Montoneros (1970)

A nova Ação Popular é uma organização política proletária, inteiramente dedicada a servir ao proletariado e por isso a todo o povo, e tem como missão dirigir a classe operária e as amplas massas populares na luta contra seus inimigos de classe [...] A nova Açao Popular guia-se pelos princípios científicos universais do marxismo-leninismo-maoismo

Programa Básico de la Acción Popular Marxista Leninista (1971)

Si nos guiamos por los epígrafes que encabezan este trabajo, cada fragmento documental parecería dar cuenta de dos organizaciones políticas con identidades, lenguajes y objetivos bien diferenciados. Entre 1970 y 1973 Açao Popular completó su tránsito al maoísmo, proceso que culminaría con la incorporación de la mayor parte de sus militantes al Partido Comunista do Brasil, en un contexto caracterizado por el endurecimiento de la dictadura, y la progresiva descomposición de las organizaciones de izquierda. Al mismo tiempo, en la Argentina, los Montoneros protagonizaron una escalada de operaciones de guerrilla urbana que les dieron una creciente gravitación en el movimiento peronista, en un escenario marcado por el auge de la protesta social y la crisis del régimen militar. ¿Quién diría que ambas organizaciones tuvieron un origen común en el catolicismo renovador? A pesar de las diferencias en sus itinerarios políticos e ideológicos, los orígenes de Açao Popular y Montoneros se remontan a las juventudes católicas latinoamericanas de la década de 
1960, radicalizadas por el Concilio Vaticano II, las revoluciones del Tercer Mundo, y el auge de las luchas sociales en la región. ¿Cómo explicar los desplazamientos ideológicos que llevaron a Açao Popular al campo de la izquierda marxista, y a Montoneros a confluir con un movimiento populista? ¿Se puede llegar a través de una comparación sistemática de los procesos políticos más generales a iluminar las causas profundas de estas diferencias, así como distinguir los elementos que fundamentaron sus coincidencias?

El objetivo de este trabajo es reconstruir las historias de Açao Popular y Montoneros, a partir del método comparativo propuesto por Marc Bloch, que consideraba válida la observación de semejanzas y diferencias entre sociedades cercanas en el tiempo y el espacio (BLOCH, 1928, p. 19; BARROS, 2007, p. 14). Siguiendo esa línea de pesquisa, estudiaremos las trayectorias de ambas organizaciones comparando sus orígenes en el catolicismo renovador, los diferentes caminos que tomaron y las culturas políticas en que se insertaron. A partir de esta aproximación podremos plantear hipótesis de trabajo sobre procesos de escala nacional, en particular la fortaleza o la debilidad de las izquierdas y el populismo en ambos países, así como los cruces y desencuentros entre ambas tradiciones. La investigación desea contribuir al estudio de procesos transnacionales como la irrupción de las dictaduras de seguridad nacional, el surgimiento de la llamada "nueva izquierda" y la lucha armada en el Cono Sur. Para el trabajo se relevó bibliografía general sobre historia reciente de Argentina y Brasil, específica sobre Açao Popular y Montoneros, y metodológica sobre historia comparada, incorporando al análisis una selección de documentos producidos por ambas organizaciones.

\section{Argentina y Brasil, entre sincronismos y asimetrías}

Desde la segunda mitad del siglo XIX, las poblaciones de Argentina y Brasil, que habían crecido de forma relativamente pareja en el marco de una inserción dependiente al mercado mundial, se diferenciaron notablemente a causa de la explosión demográfica brasileña. Hacia 1920, los 27 millones y medio de habitantes del Brasil triplicaban la población argentina, que reunía cerca de 9 
millones de ciudadanos censados (DEVOTO; FAUSTO, 2008, p. 150-151). Con el estancamiento de la inmigración masiva en 1930, la población brasileña mantuvo su ritmo de crecimiento acelerado, mientras la demografía argentina, mucho más dependiente del ciclo migratorio iniciado alrededor de 1870, exhibió avances lentos y moderados. Como contrapartida, hasta fines de la década del 30 la Argentina era un país mucho más urbanizado y alfabetizado que Brasil, situación que le permitía contar con una amplia clase media, y gozar de estándares de vida similares al de algunos países europeos. No obstante, la descentralización urbana en grandes ciudades como Belo Horizonte, São Paulo, Rio de Janeiro, Salvador de Bahía y Porto Alegre permitió a la economía brasileña tener una mayor diversificación productiva, distribución de riesgos y ventajas comparativas, en comparación a la hipertrofia del área metropolitana de Buenos Aires como centro neurálgico de la economía argentina. Si comparamos la escala de ambas economías por el Producto Bruto Interno total (PBI), este índice no presentó grandes diferencias hasta fines de los años 40, cuando Brasil superó a la Argentina: entre 1950 y 1965, el PBI brasileño medido en miles de millones de dólares pasó de 89,3 a 203,4 con un incremento del $128 \%$, mientras que el PBI argentino ascendió del 85,5 al 141,9, logrando un aumento del $66 \%$. Sin embargo, el gran salto hacia adelante se dio entre 1965 y 1989, cuando el PBI de Brasil estuvo cerca de cuadruplicarse (de 203,4 a 776,5), mientras que el PBI de Argentina tuvo un módico $50 \%$ de aumento, de 141,9 a 212,4. (VALENTINI, 2012, p. 12).

¿Que había ocurrido? Los desempeños económicos no pueden reducirse a uno o dos factores, pero hay que mencionar, en primer lugar, las diferentes maneras de inserción dependiente al mercado mundial que adoptaron los dos países: en la primera mitad del siglo XX, Brasil se dedicó a exportar café a los Estados Unidos, y la Argentina conservó sus vínculos con Inglaterra comercializando lana, carne y cereales, a medida que se imponía la hegemonía norteamericana en la región. Mientras las economías de Estados Unidos y Brasil eran complementarias, la burguesía agroexportadora argentina y fracciones de la burguesía norteamericana competían en la producción de materias primas (MONIZ BANDEIRA, 2006). En segundo lugar, hay que poner la lupa en las políticas económicas, especialmente las 
que se adoptaron en ambas naciones a partir de la crisis de 1930. La Gran Depresión afectó mucho más a Brasil por la brusca caída de los precios del café, pero la magnitud del desastre impulsó la diversificación de las exportaciones, y la temprana intervención del Estado para apoyar la producción manufacturera, a partir del modelo de industrialización por sustitución de importaciones. En Argentina, en cambio, los gobiernos de la "década infame" mantuvieron las mismas exportaciones y firmaron acuerdos comerciales desventajosos con Gran Bretaña, como el tratado Roca-Runciman de 1933. La intervención del Estado argentino fue mucho más activa, pero en principio más orientada a las finanzas que al sector industrial, área de la economía donde Brasil creció con más vigor (DEVOTO; FAUSTO, 2008, p. 235-239). Por esta razón, el PBI total de los dos países se fue equilibrando, pero al mismo tiempo existían notables diferencias en el producto bruto interno per capita, relacionadas a una estructura social más compleja y menos desigual en la Argentina, en contraste con un Brasil que conservaba algunos rasgos patriarcales, herencia del esclavismo y la República Velha: según Fernando Devoto y Boris Fausto, el crecimiento económico que había conseguido la Argentina antes de la Primera Guerra Mundial permitía que en 1940 haya 30 automóviles por cada mil personas, en comparación con 4 para Brasil; por otra parte, el consumo de energía eléctrica era de $180 \mathrm{kw}$ por persona para Argentina y 111 para Brasil, sin contar otros rubros.

Hacia 1940, Brasil y Argentina habían equilibrado sus economías. En cierta medida, la performance brasileña había sido posible por las políticas económicas de Getúlio Vargas, desde su llegada al poder en 1930. El varguismo y el peronismo, si bien tuvieron amplias coincidencias en la promoción de la industrialización, el intervencionismo estatal y la inclusión de los trabajadores urbanos en una amplia alianza de clases, también pueden ser comparados por sus diferencias: el populismo varguista puso más énfasis en la inversión productiva que en la distribución del ingreso, y careció de los matices políticos más plebeyos que distinguieron al peronismo. En contraste, el peronismo priorizó el consumo interno para impulsar el pleno empleo y la industria liviana, aunque su política de nacionalizaciones fue más agresiva, y la participación del movimiento obrero más autónoma y disruptiva que en el caso brasileño. En consecuencia, si el peronismo 
priorizó la "justicia social” dejando en un segundo plano a la modernización económica, el varguismo hizo al revés, quizás porque su punto de partida era una economía más débil, y un entramado político asociado al Antiguo Régimen de las oligarquías estaduales.

Entre fines de la década de 1950 y comienzos de los 70 los tiempos de la Argentina y Brasil se sincronizaron, compartiendo procesos y tendencias. Las presidencias de Juscelino Kubitscheck (1956-1961) y Arturo Frondizi (1958-1962) se identificaron con el desarrollismo, un modelo económico característico del nuevo orden mundial de la segunda posguerra, que intentaba conciliar el crecimiento industrial con la apertura al capital extranjero. Sin embargo, los contrastes entre los dos países eran cada vez más agudos: después de ocho meses de gobierno con una economía que crecía el $5 \%$, Frondizi aplicó un plan de estabilización para frenar la inflación y el drenaje de reservas, que profundizó las tendencias recesivas de la Argentina. Por el contrario, el ambicioso plan de metas de Kubitscheck, en un contexto más favorable para el sector externo brasileño y mayor capacidad de divisas, permitió la construcción de una nueva capital, Brasilia, con un crecimiento del $8 \%$ durante dos ańos (DEVOTO; FAUSTO, 2008, p. 326-330). Las dinámicas políticas tampoco se correspondían, ya que Kubitscheck gobernó en un clima de relativa paz social y estabilidad política, tras resolverse la crisis de sucesión abierta por el suicidio de Vargas en 1954. Aunque la huelga de 300.000 obreros paulistas en 1953 y las movilizaciones populares por la muerte del político gaúcho habían mostrado un Brasil moderno, ajeno a las consensos de las elites que predominaban en la política brasileńa, la sociedad argentina parecía más conflictiva y violenta: en 1955, aviones de la Marina bombardearon la Plaza de Mayo para asesinar al presidente Juan Domingo Perón, matando a cientos de civiles. La dictadura militar que derrocó al gobierno constitucional trato de desperonizar a la sociedad argentina sin alcanzar grandes resultados, mientras la resistencia peronista respondía con huelgas, atentados, sabotajes y hasta una guerrilla rural, los Uturuncos. Las dificultades de Frondizi para frenar las protestas obreras y la recomposición política del peronismo provocaron su caída en 1962, a causa de un nuevo golpe militar. El contexto internacional de los años 60 había cambiado, especialmente después del alineamiento de la Revolución 
cubana con la URSS. En el ambiente de una renovada guerra fría, los militares latinoamericanos intervinieron en la política doméstica para luchar contra una virtual amenaza comunista, convirtiéndose así en un actor político protagónico. En Argentina, la intromisión de las fuerzas armadas en el gobierno había sido frecuente desde 1930; en Brasil, donde los gobiernos civiles eran más estables, las fuerzas armadas también se habían politizado. A pesar de la "pax desarrollista" de Kubitscheck, el ciclo de inestabilidad institucional abierto tras la renuncia de Vargas en 1945 no se había cerrado, y el campo político brasileño se dividió en torno al legado varguista. La derecha, compuesta por la Unión Democrática Nacional (UDN) y sus aliados militares intentaron impedir la llegada al poder de los partidos herederos del varguismo, desde el moderado Partido Social Democrático (PSD), de donde provenía Kubitscheck, hasta el más populista Partido Trabalhista Brasileiro (PTB), representado por João Goulart. El Partido Comunista Brasileño (PCB), mientras tanto, pasó de la oposición intransigente a Vargas a proponer en su Declaración de Marzo de 1958 un frente único para impulsar la revolución “antiimperialista, antifeudal, nacional y democrática”, línea política que lo acercó a las posiciones del PTB (AARÃO REIS, 1990, p. 24).

En 1961 ganó las elecciones Janio Quadros, un candidato de oposición que decía ser capaz de terminar con el burocratismo y la corrupción de la era Vargas, en sintonía con el discurso antipopulista de la UDN, pero al mismo tiempo prometía una reforma agraria progresista y una política exterior independiente (DEVOTO; FAUSTO, 2008, p. 344). Sin embargo, Quadros presentó su renuncia a siete meses de iniciar su mandato, sin apoyo en el Parlamento y carente de una base política propia. En su lugar asumió el vicepresidente João Goulart, después de negociar con los militares y la oposición la formación de un régimen parlamentarista, con un gabinete que respondía a la Cámara de Diputados y tenía representantes de la UDN, el PSD y el PTB. Durante el gobierno de Goulart (1961-1964) se reunió un amplio movimiento social en apoyo de las "reformas de base", proyectadas en materia fiscal, agraria, urbana, política y educativa (AARÃO REIS, 1990, p. 45). La radicalización de obreros, campesinos, estudiantes y sectores subalternos de las fuerzas armadas permitió el surgimiento de experiencias como Açao Popular, en el marco de una sociedad 
movilizada por varios procesos interconectados: la acumulación de demandas populares en un modelo de desarrollo que no contemplaba la distribución del ingreso, las migraciones internas y la urbanización generadas por la industrialización, el ascenso de nuevas capas medias que evidenciaba una estratificación social más compleja, la alfabetización de una porción cada vez mayor de la población, rompieron la base rural de la antigua política clientelar. Así se gestó un entramado de alianzas subalternas en oposición a las elites tradicionales que incluyó a nuevos actores, como las juventudes católicas, y polarizó a la sociedad brasileña. Las manifestaciones masivas a favor y en contra del gobierno de Goulart se sucedieron, hasta que una revuelta de marineros en protesta por mejores condiciones de trabajo rompió el delgado hilo que separaba a las fuerzas armadas del poder político. El 31 de marzo de 1964, un golpe de Estado encabezado por los generales Olimpio Mourão Filho, Humberto de Alencar Castelo Branco y la oposición udenista derribó el gobierno de João Goulart.

En la Argentina, las elecciones de 1963 le dieron la victoria a Arturo Illia con un módico 25 \% del padrón electoral, ya que el peronismo no podía presentarse libremente a elecciones y la mayoría de sus simpatizantes votó en blanco. El gobierno de la Unión Cívica Radical del Pueblo (UCRP) aplicó una combinación de políticas económicas nacionalistas y distribucionistas que reactivaron la economía en el corto plazo, pero no concitaron un apoyo popular equivalente a las "reformas de base" de Goulart. La administración de Illia no pudo imponerse sobre las fuerzas armadas y los sindicatos peronistas, que se erigieron como árbitros de las políticas de la UCRP. Los militares estaban preocupados por la radicalización política en las universidades y la irrupción de organizaciones armadas como el Ejército Guerrillero del Pueblo, que en 1963 intentó sin éxito establecer un foco rural en la provincia de Salta, con la anuencia del propio Che Guevara. La Confederación General del Trabajo (CGT) demostró su fortaleza como actor político al año siguiente, con un ambicioso plan de lucha que paralizó a miles de fábricas. Aunque los indicadores económicos eran positivos y la Argentina atravesaba un período de esplendor en las ciencias y las artes, el partido militar articuló un heterogéneo bloque opositor, compuesto por sectores del empresariado, la Iglesia católica, el sindicalismo, los medios de prensa y la derecha liberal. El 
28 de junio de 1966, un golpe de Estado conducido por el general Juan Carlos Onganía derrocó al presidente Illia.

\section{Açao Popular, entre el cristianismo y el maoísmo}

En mayo de 1962, un grupo de militantes de la Juventud Universitaria Católica (JUC), la Juventud Obrera Católica (JOC) y la Juventud Estudiantil Católica (JEC) se reunieron en un convento de la orden dominicana en Belo Horizonte, para fundar una organización política independiente de la Iglesia. La radicalización de los jóvenes católicos se había iniciado alrededor de 1957, en un contexto donde se combinaron factores nacionales y transnacionales. La iniciativa desarrollista de Kubitscheck para recorrer " 50 años en 5 " no contempló las necesidades inmediatas de las clases subalternas, ya que Brasil seguía siendo un país de grandes contrastes sociales. El impulso renovador del papa Juan XXIII y la circulación de las obras de pensadores católicos como Louis-Joseph Lebret, Emmanuel Mounier y Pierre Teilhard de Chardin alimentaron la emergencia de una tendencia izquierdista en la JUC, que conjugó la crítica romántica de la Iglesia al capitalismo con la inserción en las luchas sociales. Para el ex jucista Luiz Alberto Gómez de Souza:

Maritain e mais tarde Mounier ou Teilhard de Chardin não foram adotados porque tinha ocorrido uma 'conversão' a seu pensamento, mas sobretudo porque se opunham a outros autores que se queria deixar de lado e abriam pistas que poderiam ser utilizadas, ainda que com muita liberdade. (RIDENTI, 2002, p. 7)

La crítica a la modernización desde una cosmovisión que se proponía como alternativa al capitalismo y el comunismo, hizo que varios militantes laicos realizaran, paradójicamente, un acercamiento al marxismo desde el pensamiento cristiano progresista, apropiándose de lenguajes, programas y reivindicaciones propias de la cultura de izquierdas. En abril de 1961, un acuerdo entre el Partido Comunista 
y la JUC logró que el dirigente católico Aldo Arantes sea elegido presidente de la Unión Nacional de los Estudiantes (UNE), federación que nucleaba a los alumnos de enseńanza superior. La alianza entre los jóvenes católicos y la izquierda provocó la expulsión de Arantes de la JUC, quien ya había incomodado a la jefatura de la Iglesia publicando un documento de apoyo la Revolución cubana. Como resultado de estas tensiones, el ala izquierda de la JUC decidió crear una organización no confesional, dado que la tutela eclesial se había vuelto un freno a sus ambiciones políticas, y particularmente al crecimiento en el frente estudiantil. El encuentro fundacional celebrado en el convento dominico de Belo Horizonte fue impulsado por Vinicius Caldeira Brant junto a un grupo de militantes de la JUC y la JOC que publicaban la revista Açao Popular, nombre que tomó la nueva organización (FILGUEIRAS, 2014, p. 90-92). En febrero de 1963 se realizó en Salvador de Bahía el primer Congreso del grupo, que nombró una Coordinación Nacional y redactó un Documento Base, donde el apismo rubricó su opción por el socialismo y se alineó en el campo de las izquierdas. El programa también criticó las "reformas de base", por pretender instaurar un neo capitalismo capaz de garantizar el desarrollo burgués, canalizando las tensiones provocadas por la radicalización de las masas y sus luchas contra el sistema de explotación (AARÃO REIS; FERREIRA DE SÁ, 1985, p. 44). A pesar de todo, Açao Popular colaboró con el gobierno de Goulart, empleando a sus militantes en el Ministerio de Educación, el Ministerio de Trabajo y la Superintendencia de Política para la Reforma Agraria. Pero el mayor peso de la organización estaba en el movimiento estudiantil, donde el apismo mantuvo la presidencia de la UNE durante varios años, y en el movimiento campesino, por su participación en las Ligas Campesinas, el Movimiento de Educación de Base y los sindicatos de trabajadores rurales.

El golpe militar de 1964 tomó por sorpresa a Açao Popular, ya que varios militantes fueron arrestados y otros tuvieron que escapar del país, sin poder dar una respuesta unitaria al brusco cambio de la situación política. Aunque el Documento Base había sido un intento de alear el cristianismo, el marxismo y el existencialismo en una ideología propia que reconocía la herencia de las juventudes católicas radicalizadas, los primeros ańos del régimen militar encontraron a Acción Popular buscando una nueva identidad, en un inquieto zig-zag 
de lineamientos políticos (BENEDITO DIAS, 2006, p. 143-175). La decisión de organizar la resistencia armada a la dictadura acercó a varios dirigentes apistas a Leonel Brizola, referente de la izquierda del PTB, pero en este caso la lucha armada jamás pasó de los preparativos. A medida que pasaba el tiempo y el gobierno de Castelo Branco se afirmaba en el poder, Açao Popular estrechaba relaciones con Cuba, donde importantes dirigentes como el ex sacerdote Alipio de Freitas y Paulo Stuart Wright habían viajado para realizar entrenamiento militar. En efecto, varios miembros de la organización parecían seducidos con la posibilidad de iniciar la lucha armada en Brasil (FILGUEIRAS, 2014, p. 305; GORENDER, 2014, p. 125).

En 1965, Açao Popular realizó un Encuentro Nacional en Sáo Paulo, que eligió una nueva dirección a la que se denominó Comando Nacional, y se aprobó un nuevo programa, la Resolución política. El documento valoraba la insurrección armada y la guerra de guerrillas como formas de lucha necesarias para la toma del poder, en un claro guiño a la Revolución cubana. La realidad de la organización, no obstante, era mucho más compleja que la línea, ya que varios militantes criticaban la resistencia armada como una variante "foquista" apartada de los frentes de masas. En cambio, los principales dirigentes que estaban volviendo del exilio, como Herbert José "Betinho" de Souza, Aldo Arantes, Jair Ferreira de Sá, Alipio de Freitas y Paulo Wright, coincidían en la necesidad de la violencia para derribar a la dictadura. Para llevar esta idea a la práctica, se creó una comisión militar, con la tarea de capacitar en el manejo de armas y explosivos a los militantes (GORENDER, 2014, p. 125). Pero un año después, un hecho armado contribuyó a modificar nuevamente el derrotero político de la organización: el 25 de julio de 1966 estalló una maleta con explosivos en el aeropuerto de la ciudad de Recife. El objetivo era matar al Ministro de Guerra Arthur da Costa e Silva, pero por problemas técnicos el avión que lo debía trasladar no llegó a despegar. El atentado, que provocó dos muertos y quince heridos, fue preparado por un grupo de militantes de Pernambuco dirigidos por Alipio de Freitas que integraban la comisión militar. (FILGUEIRAS, 2014, p. 307-308). El fracaso de la acción, que no había sido consultada con el Comando Nacional, llevó al cierre de la comisión militar y aceleró la búsqueda de una 
nueva identidad, capaz de conciliar las tendencias movimientistas y foquistas de la organización.

El acercamiento a China se volvió fundamental para el cambio de línea política de Açao Popular. Si bien existían contactos previos, la primera delegación oficial llegó a Beijing en 1967, en plena Revolución Cultural. Los revolucionarios chinos ofrecían formación política antes que capacitación militar, algo que la comitiva brasileña aceptó con entusiasmo por la mala experiencia que habían tenido en Cuba, donde los apistas recibieron entrenamiento guerrillero pero se les prohibió avanzar en el debate de ideas.1 Los chinos insistían en el trabajo de masas, tenían una concepción "científica" del socialismo y una estrategia de guerra popular prolongada, elementos que parecían atenuar las diferencias entre movimientistas y foquistas. ${ }^{2}$ Por otro lado, los dirigentes de Açao Popular encontraban por fin una identidad homogénea, que les permitiría posicionarse en el campo de las izquierdas como una alternativa al viejo Partido Comunista Brasileńo y a las organizaciones político-militares que iban a aparecer en los ańos siguientes. En abril de 1967, Açao Popular publicó una Resolución sobre el debate teórico-metodológico, que criticó a los programas anteriores por dar una definición ideológica del socialismo sin apoyarse en el marxismo, valorado ahora como ciencia de la historia, la política y la sociedad. Según el documento, lo importante era estudiar la teoría revolucionaria, ya que otra cosa sería: “... negar a possibilidade de centralizar o debate no estudo do marxismo, e pretender estudar, ao mesmo tempo, o pensamento de Teilhard de Chardin, Emanuel Mounier, Bertrand Russel, etc." (FILGUEIRAS, 2014, p. 373). La mutación cultural hacia un marxismo que excluía la matriz cristiana y existencialista originaria de Acción Popular encontró un puente en el maoísmo, pero también en el estructuralismo: entre 1966 y 1967, un grupo de apistas que se encontraba en París cursó varios seminarios con Louis Althusser, impulsando la circulación de sus ideas en la organización. Así pues, la distinción entre ciencia e ideología contribuyó al divorcio formal del marxismo y el cristianismo (RIDENTI, 2002, p. 48-49). El tránsito del cristianismo liberacionista al maoísmo no implicaba solamente un cambio de línea o de estrategia, sino la reinvención de la cultura política de la organización, "uma verdadeira revoluçao pessoal, com uma mudança 
completa na perspectiva de vida e no estilo de militancia de muitos de nossos quadros" (FILGUEIRAS, 2014, p. 373; LOWY, 1999).

La primera mitad de 1968 significó el punto más alto de las protestas contra la dictadura en Brasil, que ya incluían acciones armadas de guerrilla urbana. Para Açao Popular, que había echado raíces en el movimiento obrero, campesino y estudiantil, fue en cambio un momento de crisis interna, debido a la nueva orientación política adoptada por la dirección. Si nos guiamos por la Autocrítica del Comando Nacional redactada aquel año, el proceso de homogeneización cultural parecía no avanzar de acuerdo a lo esperado. La dirigencia apista creía "[...] necessário reconhecer que existe contradição entre materialismo dialético e religião e fazer um trabalho de persuasão a este respeito, mas acima de tudo concentrar esforços na transformação prática dos militantes crentes" (RIDENTI, 2002, p. 28). En las semanas siguientes a la ola de movilizaciones de abril y mayo estalló la lucha entre fracciones internas: la gota que colmó el vaso fue la publicación de Los seis puntos por un sector de la dirección que integraban Aldo Arantes, Jair Ferreira de Sá, Duarte Pereira, Haroldo Lima y Paulo Stuart Wright, conocidos como la Corriente 1. En respuesta, Vinicius Caldeira Brant, Sergio Bezerra de Menezes, Alipio de Freitas, María Docarmo Biapina y Altino Dantas redactaron las Dos posiciones, formando una tendencia que recibió el nombre de Corriente 2. En líneas generales, los puntos de quiebre entre ambas fracciones eran el modelo revolucionario a seguir (China o Cuba), el papel de la lucha armada (guerra popular prolongada vs. foco rural), el tipo de revolución (nacional-democrática o socialista inmediata) y la caracterización de la sociedad brasileńa (semifeudal y semicolonial o capitalista dependiente).

Los seis puntos operaron una completa mímesis con el vocabulario político maoísta: el partido proletario debía guiarse por la teoría marxista-leninista, seguir el pensamiento del presidente Mao-Tsé-Tung, entendido como la tercera etapa del marxismo, practicar la crítica y la autocrítica (FILGUEIRAS, 2014, p. 528). La Corriente 2 también reclamaba su pertenencia al campo de las izquierdas, citaba a Lenin y condenaba al "revisionismo soviético", pero reunía a un heterogéneo grupo compuesto por los partidarios del foco rural, los estructuralistas y aquellos que rechazaban la revolución por etapas. Aunque la ruptura era inevitable y los opositores 
al giro maoísta terminaron por ser expulsados, las dos tendencias coincidían en su balance de la primera Açao Popular, criticada por su origen pequeńo-burgués y antimarxista desde la Corriente 1, o cuestionada por la Corriente 2 debido a su concepción moralista de la historia. ${ }^{3}$ Otro tema que dividió aguas en Açao Popular fue la integración a la producción entre 1968 y 1970, política que desplazó a los cuadros intelectuales y estudiantiles hacia ámbitos fabriles o rurales. La finalidad de la proletarización era, según sus defensores, forjar una conciencia revolucionaria en los militantes de clase media volcándolos al trabajo productivo, entendido como actividad práctica fundamental y fuente de conocimiento (TSE-TUNG, 1976, p. 318-332). La integración a la producción continuó con las prácticas del catolicismo renovador, como indicaba Carlos Aumond en 1966:

Mais importante do que tudo, entretanto, nos parece a identificação profunda e pessoal do militante profissionalizado com o povo operário e camponês. A experiência dos revolucionários do Vietná foi resumida por Ho Chi Minh na conhecida política dos três preceitos, que assim se enuncia: viver junto, comer junto e trabalhar junto. Esta identificação é tão importante que a Igreja Católica a adotou para sua pastoral operária com a experiência dos padres operários. (RIDENTI, 2002, p. 30)

La integración a la producción, sin embargo, fue abandonada hacia 1970, dejando un saldo ambiguo con valoraciones positivas y condenas en bloque. Para Jacob Gorender la experiencia fue un fracaso, ya que desestructuró el poderoso frente estudiantil de Acción Popular (GORENDER, 2014, p. 128). Betinho, que permaneció en Acción Popular después de la ruptura de 1968 y vivió en carne propia la proletarización, realizó un balance posterior aún más duro, al criticar de forma mordaz las semejanzas entre cristianismo y maoísmo:

O maoísmo caiu melhor na minha estrutura de inspiração cristã. Um católico praticante fervoroso pode virar um maoísta numa questấo de segundos, porque você tem Deus, que é o Mao, tem o camarada que é chefe, você tem a revolução que 
é inexorável [...] Tem a bíblia vermelha, que é pequenininha e fácil de ler. (RIDENTI, 2002, p. 54)

La asunción del maoísmo no garantizó el fin de los conflictos internos, ya que al poco tiempo surgieron tensiones por el progresivo acercamiento entre Açao Popular y el Partido Comunista do Brasil (PCdoB), que se había formado en 1962 y tenía excelentes relaciones con China. Algunos militantes creían que se debía construir un nuevo partido proletario y apoyaban las tareas socialistas como prioridad revolucionaria, a pesar de su maoísmo declarado. Otros sostenían que el partido proletario era el PCdoB, y defendían sus tesis de revolución nacional-democrática. La dirección apista, que permanecía en la clandestinidad debido a la intensa represión que estaba cayendo sobre el conjunto de la izquierda revolucionaria, optó por una solución de compromiso: en 1971 se aprobó un Programa Básico que trató de remendar las tensiones estratégicas con el concepto de "revolución ininterrumpida por etapas", cambió el nombre de la organización a Açao Popular Marxista Leninista (APML), y reemplazó los comandos por comités. Sin embargo, la mayoría del Comité Central, dirigido por Aldo Arantes y Haroldo Lima, eligió disolver la organización, cumpliendo con el requisito exigido por el PCdoB para unirse a sus filas. La minoría, encabezada por Jair Ferreira de Sá y Paulo Wright se negó a desmantelar la APML, razón por la cual el proceso de ruptura se extendió hasta comienzos de 1973. Mientras un sector de la organización se unió al PCdoB, que llegaba a la fusión muy golpeado por la persecución de la dictadura, el resto de APML se quedó en la organización hasta el II Congreso realizado a fines de 1980 , donde la mayoría de sus militantes se integró al naciente Partido de los Trabajadores.

\section{Montoneros, una vanguardia armada del peronismo}

La organización político-militar Montoneros se formó en Argentina hacia 1968, a partir de la fusión de varios grupos juveniles católicos galvanizados por el Concilio Vaticano II, el pensamiento 
cristiano progresista, las revoluciones del Tercer Mundo y el peronismo combativo. Buena parte de los futuros integrantes de Montoneros se conocieron en las redes animadas por el ex seminarista Juan García Elorrio, como los Comandos Camilo Torres y la revista Cristianismo y Revolución, medio de prensa publicado entre 1966 y 1971 que funcionó como espacio de convergencia entre el cristianismo liberacionista, la izquierda peronista y las organizaciones armadas (MORELLO, 2003). Incorporando las ideas marxistas de John William Cooke, ex delegado de Perón que quería convertir al peronismo en un partido revolucionario, y adoptando la lectura del revisionismo histórico de izquierdas de Jorge Abelardo Ramos y Juan José Hernández Arregui, quienes relacionaban el peronismo con las luchas populares del siglo XIX, este sector de las juventudes católicas veía al peronismo como una versión argentina de los movimientos de liberación nacional que revolucionaban al Tercer Mundo. El pasaje del cristianismo liberacionista a la idea de construir una organización armada de identidad peronista y objetivos socialistas fue veloz: tras viajar al encuentro de la Organización Latinoamericana de Solidaridad en Cuba y entrenarse militarmente, a fines de 1967 un grupo de militantes del Comando Camilo Torres encabezado por Fernando Abal Medina y Emilio Maza rompió con García Elorrio, criticado por poner las actividades de la revista por encima de los preparativos de la lucha armada (CAMPOS, 2010, p. 91-96).

Hasta 1970, los grupos originarios de Montoneros participaron de acciones militares innominadas, como desarmes a policías, asaltos a entidades bancarias y depósitos de armas, con el propósito de foguear a los militantes y montar una infraestructura político-militar. Con el estallido de la rebelión popular del Cordobazo en 1969, la organización entendió que estaban maduras las condiciones para darse a conocer públicamente. ${ }^{4}$ El 29 de mayo de 1970, en el aniversario de las jornadas insurreccionales de Córdoba, un comando montonero secuestró a Pedro Eugenio Aramburu, uno de los jefes del golpe de Estado que había derrocado a Perón. Tres días después, el militar retirado fue asesinado de cuatro disparos, tras ser sometido a un juicio revolucionario. La conmoción producida por el magnicidio precipitó la renuncia de Onganía, pero las cosas no terminaron allí: el 1 de julio, Montoneros ocupó la localidad cordobesa de La Calera, esta 
vez con bajas importantes como el dirigente Emilio Maza, muerto por las fuerzas de seguridad (GILLESPIE, 1989, p. 126-127). Si bien los montoneros parecían más interesados en exhibir hechos armados que por la producción teórica, aprovecharon la difusión mediática de sus acciones para dar algunas definiciones políticas:

Somos peronistas aunque provengamos de distintos orígenes y formaciones. El peronismo tiene una doctrina creada en 1945, que se fue reelaborando y actualizando durante los veinticinco ańos posteriores. Esta doctrina se sintetiza en las tres banderas del Movimiento: Independencia Económica, Justicia Social y Soberanía Política. Estas tres banderas en 1970 se expresan a través de la necesidad de lograr un desarrollo económico independiente y una justa distribución de la riqueza, dentro del marco de un sistema socialista que respete nuestra historia y nuestra cultura nacional. Por otro lado, la doctrina fue definida por su creador, el general Perón, como profundamente nacional, humanista y cristiana, respetuosa de la persona humana sobre todas las cosas 5 .

En este pasaje conviven matrices culturales diferentes, unidas por la lectura del peronismo como una revolución inconclusa que el socialismo y la lucha armada debían llevar hasta sus últimas consecuencias. El énfasis en la "persona humana" y lo cristiano de la doctrina justicialista son huellas discursivas que, dejadas adrede o no, segregaban a los Montoneros de la izquierda revolucionaria y delataban sus orígenes intelectuales, vinculados al pensamiento cristiano progresista. Por otra parte, el populismo distributivo y nacionalista de las tres banderas peronistas coincidía sin mayores precisiones con el socialismo. Para concretar este programa, Montoneros sostenía una estrategia de guerra popular:

Ésta presenta distintas características, debe ser total, nacional y prolongada. Le digo total porque supone la destrucción del Estado capitalista y de su ejército, como previos a la toma del poder por el pueblo. Hablamos de nacional, porque su sentido es el de la emancipación del dominio extranjero, 
a la par que la reivindicación del pueblo argentino. Y por último la calificamos de prolongada, porque hay que formar el ejército popular, lo que implica tiempo para desarrollarlo y además, debido a las características del ejército enemigo al cual no es posible derrotar en un combate y sí, en cambio, desgastarlo en la lucha a través del tiempo ${ }^{6}$.

Coincidir con la guerra popular prolongada no significaba la asunción plena del maoísmo, sino más bien el uso instrumental de una categoría que se sumaba al collage de la ecléctica identidad montonera. Como parte de la nueva izquierda, los guerrilleros peronistas veían a la Revolución china como un socialismo renovado, antiburocrático y defensor de la vía armada para combatir el imperialismo. Pero también parecían aceptar los conceptos de foco guerrillero y propaganda armada que habían popularizado el Che Guevara y Régis Debray, cuando sostenían que el secuestro de Aramburu era "[...] el primer hecho militar realizado por una organización revolucionaria que implica por sí solo definirse políticamente". 7 Las redadas policiales y el asesinato de sus principales dirigentes entre julio y septiembre de 1970 empujaron a Montoneros al borde de la extinción, ya que los contactos se redujeron al mínimo y declinaron las acciones armadas. Sin embargo, a lo largo de 1971, lo que era una laxa federación de agrupaciones provinciales se convirtió en una estructura nacional (LANUSSE, 2007, p. 16-18). En agosto se realizó un Congreso Nacional, que impulsó la formación de una conducción única compuesta por los jefes regionales y discutió una "Línea Político Militar", programa de circulación interna aprobado a principios de 1972. El documento proponía como objetivos revolucionarios la liberación nacional y el socialismo, definido como la socialización de los medios de producción y la abolición de la propiedad privada en el marco de una economía planificada. La estrategia de guerra revolucionaria delimitaba un campo de fuerzas dado por la lucha de clases, donde la principal oposición era entre el peronismo, representado por los trabajadores junto a los sectores de clase media aliados, y el antiperonismo, compuesto por el imperialismo, la oligarquía terrateniente, la mediana y la gran burguesía (BASCHETTI, 2004 , p. 249-270). Si la lucha armada era vista como una estrategia a la que debían subordinarse las demás formas de lucha, la consecuencia 
lógica del planteo era que Montoneros aspiraba a convertirse en la vanguardia del movimiento peronista.

La reestructuración de 1971 generó las condiciones para el crecimiento de la organización, moderado en buena medida por las propias prácticas conspirativas que prevenían la infiltración del aparato represivo (LANUSSE, 2007, p. 23). Desde el punto de vista montonero, se estaba pasando del "foco" a la "infección", es decir, de la pequeña organización clandestina a la inclusión de las masas en un movimiento armado, gracias al ejemplo catalizador de las acciones guerrilleras (SALAS, 2009, p. 7). Así pues, la estructura organizativa se modificó para incorporar nuevos militantes: debajo de las Unidades Básicas de Combate integradas por guerrilleros, surgieron las Unidades Básicas Revolucionarias, dotadas de cuadros intermedios que conectaban a la organización armada con los movimientos sociales (LANUSSE, 2007, p. 24). El prestigio ganado en el campo peronista con el secuestro de Aramburu, la rapidez de reflejos para sumarse al proyecto electoral de Perón cuando pocos creían en su regreso, y la politización hacia la izquierda de un sector de las capas medias y obreras, transformaron en los primeros meses de 1973 a Montoneros en una organización político-militar con frentes de masas capaces de movilizar a miles de simpatizantes. En este período, conocido entre los militantes como el "engorde", nacieron la Juventud Peronista Regionales (JP), la Juventud Trabajadora Peronista (JTP), el Movimiento Villero Peronista (MVP), la Juventud Universitaria Peronista (JUP), la Unión de Estudiantes Secundarios (UES) y la Agrupación Evita (AE), entre otras organizaciones de base que respondían a la dirigencia montonera. Montoneros también absorbió a organizaciones preexistentes como el comando Descamisados, cuyos orígenes se remontaban a la Democracia Cristiana, y las Fuerzas Armadas Revolucionarias, formada por militantes provenientes del Partido Comunista. Por otro lado, la organización desarrolló una intensa labor periodística para disputar la arena de la opinión pública, con periódicos de tirada masiva como Noticias, El Descamisado y La causa peronista.

Las reiteradas protestas sociales y el desafío de la guerrilla desgastaron a la dictadura militar de tal modo, que el presidente de facto Alejandro Agustín Lanusse decidió programar una apertura política controlada por las fuerzas armadas. Los montoneros colaboraron con la campaña presidencial del candidato peronista Héctor Cámpora, 
que triunfó en las elecciones del 11 de marzo de 1973 con el aval de Perón. De esta manera, la llamada Tendencia Revolucionaria, que congregaba al peronismo montonero y sus aliados consiguió doce diputados nacionales, presencia en gobernaciones provinciales y universidades nacionales (SALAS, 2009, p. 6). La creciente intervención de Montoneros en el espacio público, y su adhesión a la política frentista de Perón acarreó un cambio en varios puntos de su estrategia:

2.2.1.2. Construcción del frente. Responde a la necesidad de enfrentar a los monopolios desde una relación de fuerzas superior para lo cual es imprescindible ampliar la base de sustentación (el campo de fuerzas aliadas). No comprendemos esta política porque concebimos a la lucha del movimiento de liberación nacional - el peronismo - como una tarea independiente sin necesidad de política de frente; esta incomprensión deriva fundamentalmente de caracterizar a priori la mediana burguesía en el campo enemigo sin analizar las contradicciones que la política de penetración imperialista le puede provocar (ver Línea Político-Militar). (BASCHETTI, 1996, p. 577).

En el Boletín interno n.1 se criticaba al foco guerrillero como una concepción política incapaz de hacer frente a los desafíos de la nueva etapa, en clara referencia al programa de 1971, que había definido una acentuada polarización entre los trabajadores y la burguesía. El proyecto de "reconstrucción nacional" de Perón, apoyado en una alianza de clases con la burguesía industrial y una apertura hacia los partidos políticos tradicionales, llevó a nuevas definiciones: la "contradicción principal antagónica” era nación-imperialismo, mientras aquellas que dividían al pueblo de la mediana burguesía se agrupaban dentro de las contradicciones secundarias. La reconstrucción nacional era vista como la primera etapa de la liberación nacional, que a su vez iba a exacerbar las contradicciones necesarias para la transición al socialismo. El mismo proceso de liberación nacional forjaría una conciencia socialista, que se debía desarrollar "[...] a través de la práctica de las masas, de sus militantes más conscientes, de la conducción del general Perón, no apareciendo como algo dado a priori” (BASCHETTI, 1996, p. 582-583). La llegada de Perón al país frenó 
las expectativas que tenía Tendencia Revolucionaria con el retorno del peronismo al poder. Hasta los primeros meses de 1973, el anciano líder había apoyado las acciones de Montoneros para contrarrestar las tendencias negociadoras de la CGT y los políticos peronistas, pero también para presionar al régimen militar con una salida violenta si no se garantizaban elecciones libres. Con Cámpora en el gobierno, Perón empezó a atacar frontalmente a la Tendencia Revolucionaria, para lo cual se acercó a los jefes sindicales y a los sectores más conservadores del movimiento. Mientras en los discursos de circulación pública los Montoneros se volcaban a un frenético malabarismo argumentativo para hacer coincidir sus posiciones con las de Perón, a nivel interno las diferencias parecían evidentes, como muestra la Charla de la Conducción Nacional ante las agrupaciones de los frentes de 1973:

La ideología de Perón es contradictoria con nuestra ideología porque nosotros somos socialistas, es decir, para nosotros la Comunidad Organizada, la alianza de clases es un proceso de transición al socialismo [...] Estas contradicciones ideológicas se pueden observar en distintos elementos, por un lado la caracterización del socialismo nacional; cualquiera sabe que Perón caracteriza como socialismo nacional tanto a China, como a Inglaterra o Suecia. Lo que pasa es que para nosotros no es así: China es un estado socialista, Inglaterra no. ¿Por qué nosotros decimos socialismo nacional? Porque la primera intuición politica de las masas es el nacionalismo y no el socialismo y porque aparte el nacionalismo permite la alianza de clases en función antiimperialista, es decir en la transición hacia el socialismo (BASCHETTI, 1996, p. 274, grifos nossos).

Las tensiones con el liderazgo de Perón fueron en aumento, especialmente después del asesinato por un comando montonero de uno de sus aliados más cercanos, el secretario general de la CGT José Ignacio Rucci. Al mismo tiempo, el enfrentamiento con Perón provocó la ruptura de un importante sector que fundó la Juventud Peronista Lealtad, rechazando la continuidad de la lucha armada en el marco de un gobierno peronista y la desobediencia al anciano líder, elegido como presidente en septiembre de 1973. A partir del 
mes de diciembre, los choques entre la derecha y la izquierda peronista se profundizaron por el surgimiento de la Alianza Anticomunista Argentina, organización que alcanzó notoriedad por sus atentados contra militantes de izquierda, sindicalistas, intelectuales y artistas. La muerte de Perón en julio de 1974 y la asunción de la vicepresidente Isabel Martínez, cercana a las posiciones más duras de la derecha peronista, no hizo más que deteriorar una situación política ya empantanada por la crisis económica, las protestas sociales y la insurgencia armada. Con el incremento de la represión legal e ilegal, la Conducción Nacional de Montoneros decidió el retorno a la clandestinidad, replegándose de locales barriales, universidades y fábricas, donde los militantes de la Tendencia Revolucionaria estaban más expuestos (SALAS, 2009, p. 10). Sin embargo, la organización participó en 1975 de diversos proyectos como el Partido Auténtico y las coordinadoras fabriles, que se destacaron en las movilizaciones masivas de junio en apoyo al paro general lanzado por la CGT, contra el ajuste del gobierno de Isabel Martínez. El gran cambio en las políticas montoneras sobrevino a mitad de año, cuando se inició la "Campaña de Ofensiva Táctica", destinada a insertar a los militantes de los frentes de masas en unidades de combate, con vistas a construir un ejército montonero. Al mismo tiempo, la Conducción Nacional sacó como conclusión de las movilizaciones de junio el agotamiento del peronismo como identidad de la clase obrera, lo que habilitaba su reemplazo por el montonerismo (SALAS, 2007, p. 32-40). La transformación de las estructuras organizativas y la línea política cristalizó en la formación de un partido de vanguardia de ideología marxista-leninista, que debía superar a la más flexible organización político-militar, responsable de fusiones pero también de rupturas y filtraciones. En resumen, Montoneros creó una nueva organización de cuadros culturalmente homogénea y abocada a las prácticas militares, que la convirtió en una de las guerrillas más poderosas de América Latina. Antes y después del golpe de Estado que colocó en el poder a las fuerzas armadas en 1976, la organización fue capaz de realizar secuestros millonarios, producir armas en sus propias fábricas y organizar atentados con explosivos, mientras la mayor parte de sus militantes caían secuestrados o asesinados por las fuerzas de seguridad. Pero la eficacia de la máquina de guerra montonera debilitó 
el vínculo con las organizaciones de base que habían servido para mediar entre los guerrilleros y la sociedad civil entre 1972 y 1975 , en un contexto represivo que se volvió irrespirable para las prácticas políticas públicas. Hacia 1979, la dirigencia montonera en el exilio planeó una Contraofensiva que debería catapultar al partido como vanguardia del movimiento de masas contra la dictadura militar, pero el proyecto político de Montoneros ya estaba acabado.

\section{Orígenes comunes, trayectorias bifurcadas}

A partir de esta primera aproximación a las militancias de Açao Popular y Montoneros, podemos trazar algunos lineamientos para su comparación, teniendo en cuenta las diferencias y semejanzas de los procesos históricos más generales de Argentina y Brasil entre 1960 y 1980. En principio, ambas organizaciones partieron de un origen común, la tendencia a la autonomización que experimentaron las ramas especializadas de Acción Católica desde los años 50, a partir de su inserción entre trabajadores, campesinos y estudiantes. En los dos casos, el giro modernizador del Concilio Vaticano II, el prestigio de las revoluciones tercermundistas como modelo alternativo y el peso específico de procesos locales, como el movimiento de apoyo a Goulart en Brasil y el golpe militar de 1966 en Argentina, precipitaron la ruptura de un grupo de activistas laicos con los sectores católicos más conservadores. En ambos casos, el mandato conciliar de la opción de los pobres y las ideas de pensadores católicos progresistas como Mounier, Teilhard de Chardin y Lebret fueron apropiados desde el punto de vista de la periferia oprimida del sistema capitalista mundial, produciendo una síntesis radical (LOWY, 1999, p. 110). La contigüidad de estas experiencias refiere a un proceso de matriz transnacional, que condicionaba la realidad argentina y brasileña a la acción de las mismas grandes causas. El método de "ver, juzgar, actuar", sistematizado por el sacerdote belga Joseph Cardjin para empujar la Acción Católica a una práctica transformadora de la sociedad según principios cristianos provocó el efecto inverso, ya que fue la conflictividad social y política la que cambió y secularizó 
parcialmente a un sector de las juventudes católicas argentinas y brasileñas, que terminaron construyendo organizaciones no confesionales.

Si ampliamos nuestro ángulo de visión a las dinámicas locales de la Iglesia católica, las coincidencias abren paso a las primeras diferencias. Vistas en una perspectiva de mediano plazo, las corrientes renovadoras parecían tener mayor fuerza institucional en Brasil que en Argentina. Si hacia 1952 se creó la Conferencia Nacional de los Obispos de Brasil (CNBB), que levantó la bandera de la reforma agraria y expresó un catolicismo interesado por las demandas populares, en Argentina el enfrentamiento entre la Iglesia y el peronismo alejó al clero de las clases subalternas y sus reclamos. Desde luego, en Brasil las tendencias conservadoras eran dominantes, y tenían suficiente poder como para marginar a obispos progresistas como Helder Cámara, sin contar la presencia masiva de católicos en la Marcha de la Familia con Dios por la Libertad realizada en marzo de 1964, que contribuyó a la caída de Goulart. No obstante, la escalada represiva del régimen militar desde 1968, que incluyó episodios de tortura a religiosos comprometidos con la resistencia a la dictadura, convirtió a la Iglesia brasileńa en una de las principales fuerzas opositoras, con un activo papel en la denuncia de violaciones a los derechos humanos. Por el contrario, la Iglesia argentina cultivó estrechos lazos con las fuerzas armadas, apoyó al régimen castrense inaugurado en 1976, y justificó la represión hasta que el gobierno militar entró en crisis (DEVOTO; FAUSTO, 2008, p. 418-419). A pesar de las tensiones entre progresistas, integristas y conservadores, el ambiente católico brasileño de principios de los años 60, con la CNBB apoyando las "reformas de base", parecía propicio para la formación de un movimiento político de proyección pública y amplias bases sociales como fue Açao Popular en sus orígenes. En cambio, la afinidad entre Iglesia y dictadura en la Argentina, con una jerarquía eclesiástica que para los católicos más radicalizados siempre se ponía del lado de los poderosos, junto a la creciente asfixia de la vida política, social y cultural desde 1966, hizo más atractiva la opción por las armas y la clandestinidad.

¿Por qué dados estos orígenes comunes, Montoneros se convirtió en una guerrilla peronista, y Açao Popular en una organización afín al maoísmo? Para aproximarse al problema hay que tener en 
cuenta varios factores, como los movimientos políticos, las corrientes intelectuales, las estructuras sociales y la experiencia de las organizaciones en su propio devenir. En primer lugar, llama la atención el peso diferencial de tradiciones políticas como el populismo y las izquierdas en cada sociedad; por ejemplo, el varguismo brasileño no tuvo un arraigo en las clases subalternas y una cohesión a lo largo del tiempo tan grande como la que logró el peronismo en la Argentina, algo que puede deberse a distintas razones: el énfasis de Vargas en la modernización económica y de Perón en el reformismo social, el mayor desgaste del varguismo en sus largos ańos de gobierno en oposición al primer peronismo, que por su abrupto final y la resistencia de sus bases había adquirido un matiz épico y utópico para los jóvenes montoneros, en fin, el perdurable liderazgo de Perón frente a los límites de Goulart y Brizola para heredar el intransferible carisma de Vargas, fueron algunas de las diferencias más notables. En consecuencia, el populismo aparecía como un proyecto débil a los ojos de Açao Popular, sobre todo después de que el golpe militar de 1964 truncara su participación en el gobierno del PTB. Por el contrario, para Montoneros el peronismo ofrecía un gran atractivo como alternativa revolucionaria. Un síntoma de esta asincronía en la recepción del peronismo y el varguismo por los movimientos radicales de los años 60 podemos verla en la izquierda intelectual: en la Argentina, la persistencia del peronismo como identidad popular abrió la posibilidad de una valorización positiva del populismo, como se puede ver en la producción de Juan José Hernández Arregui y Jorge Abelardo Ramos, en el movimiento universitario de cátedras nacionales o en revistas como Cristianismo y Revolución, Pasado y Presente y Envido. En Brasil, en cambio, la producción cultural de izquierdas durante la dictadura se destacó por sus críticas al populismo, como ocurrió con las colaboraciones de Francisco Weffort en la revista Civilizaçao brasileira, en Caio Prado Jr. con su libro $A$ revoluçao brasileira, y en Octavio Ianni con su trabajo $O$ colapso de populismo (GORENDER, 2014, p. 84).

Un segundo factor a tener en cuenta es el grado de desarrollo de las izquierdas en cada país, ya que al fin y al cabo Acción Popular terminó fundiéndose con un partido de ideología marxista-leninista-maoísta, mientras Montoneros intentó transitar al socialismo desde 
un movimiento populista. A primera vista, una hipótesis sencilla sería considerar la opción apista por el maoísmo por la mayor fortaleza de la izquierda brasileńa en comparación a sus pares argentinos, pero si observamos la trayectoria de ambos movimientos desde las primeras décadas del siglo XX hasta la coyuntura de 1970, el panorama es mucho más complejo. En la Argentina, el temprano desarrollo de la izquierda anarquista, socialista y comunista coincidió con el mayor peso de factores estructurales como la urbanización, la alfabetización y la inmigración europea, mientras en el nordeste brasileńo hacia 1930 aun podían verse movimientos mesiánicos como el del beato José Lourenço en Ceará, o las partidas armadas de los cangaçeiros, que se dedicaban al bandolerismo rural. Sin embargo, el PCB tuvo protagonismo en importantes segmentos del movimiento obrero, $y$ cuando no estuvo proscrito logró aceptables performances electorales. La popularidad del secretario general Luiz Carlos Prestes, un ex militar proveniente del movimiento antioligárquico de los tenentes, y la alianza con los sindicatos del PTB, que permitió el triunfo de un dirigente antiburocrático en 1961 al frente de la Confederación Nacional de los Trabajadores de la Industria (CNTI), parecía una realidad imposible de trasladar a la Argentina, donde el primer peronismo había marginado a las izquierdas del movimiento obrero. La instauración de los gobiernos autoritarios de Castelo Branco y Onganía a mediados de la década del 60 ayudó a modificar este panorama: si en Brasil las izquierdas cayeron en un creciente aislamiento, en buena medida por la eficacia del terror y el éxito económico de la dictadura, en la Argentina por el contrario las izquierdas marxistas y peronistas consiguieron una amplia recepción, debido a la mayor conflictividad social, la crisis del régimen militar y la politización de sectores de la clase media y los trabajadores (DEVOTO; FAUSTO, 2008, p. 410). Da la sensación entonces que la inclinación de Açao Popular por el maoísmo no se debió tanto a la gravitación secular de la izquierda en la vida política brasileña, sino más bien a la debilidad del populismo varguista como alternativa de cambio, en un tiempo donde las opciones revolucionarias parecían limitarse al PCB y sus múltiples escisiones. En la Argentina, por el contrario, el arraigo del populismo produjo fraccionamientos hacia el peronismo en el nacionalismo de derechas, como ocurrió con la Alianza Libertadora 
Nacionalista y el Movimiento Nacionalista Revolucionario Tacuara, en el catolicismo con el comando Descamisados y los Montoneros, y en la izquierda con las Fuerzas Armadas Revolucionarias y el ERP 22 de agosto, solo para citar algunos ejemplos.

En tercer lugar, Açao Popular y Montoneros se formaron en un espacio de experiencias políticas, culturales y organizativas donde también se pueden hallar rasgos distintivos y comunes. En la Argentina y Brasil existió un acercamiento entre militantes de izquierda y el catolicismo renovador similar al diálogo entre cristianos y marxistas que se estaba desarrollando en Europa occidental a partir del Concilio Vaticano II, pero con derivaciones más inmediatamente políticas que filosóficas. En Brasil, el intercambio empezó hacia 1960, y tuvo como consecuencia directa el triunfo de la JUC y el PCB en las elecciones de la UNE, resultado que precipitó la creación de Acción Popular como organización de izquierda independiente de la Iglesia (MARGARIA, 2012). Los jóvenes católicos que iban a fundar Montoneros participaron del diálogo entre cristianos y marxistas más tarde, pero priorizaron sus relaciones con figuras de la emergente izquierda peronista, como John William Cooke y Raimundo Ongaro. Por otra parte, la peronización de los jóvenes montoneros parece haber secularizado sus prácticas políticas, ya que salvo los primeros documentos, la abrumadora mayoría de su producción discursiva careció de elementos explícitamente religiosos. Si bien en una fecha tan lejana como 1979 el padre Jorge Adur oficiaba como capellán del Ejército Montonero, no parece que la religiosidad haya superado los límites de la privacidad, esto sin negar las contigüidades entre religión y política. En Açao Popular, por el contrario, la ideología propia del Documento Base, capaz de combinar el marxismo con el pensamiento católico humanista y existencialista, se convirtió en un problema para los apistas que inspirados por el maoísmo o el estructuralismo proclamaron la incompatibilidad entre cristianismo y marxismo, como indica la Resolución sobre el debate teórico-metodológico de 1967 y la Autocritica del Comando Nacional de 1968. ${ }^{8}$

¿Qué lugar ocupó el marxismo en la cultura política de cada organización? Desde los primeros años de Açao Popular es notoria la persistente búsqueda de una nueva identidad política, que los llevará del cristianismo liberacionista al foquismo y finalmente el maoísmo. 
Los primeros apistas usaron al marxismo como una herramienta de análisis que les proporcionó un vocabulario crítico de la modernización capitalista, allí donde no alcanzaban las palabras del discurso moralista católico. El padre Lage, quien participó de las sesiones de discusión que dieron lugar al Documento Base, llama la atención sobre "el gusto por el análisis" de los fundadores de Açao Popular y su certeza en la necesidad de una teoría para guiar las prácticas revolucionarias (FILGUEIRAS, 2014, p. 93). Esta primacía de la teoría, es decir la preocupación por definir si la sociedad brasileña era feudal o capitalista, el tipo de revolución, sus actores protagónicos y secundarios, era un rasgo que se mantuvo incluso durante el giro foquista de la organización. El incidente del aeropuerto de Recife fue un evento contingente que alejó a Açao Popular de Cuba y la acercó a China, una suerte de trauma que desacreditó el recurso a la lucha armada inmediata, y presionó a la dirección para uniformizar la identidad de los militantes. La posterior reivindicación del marxismo como ciencia de la revolución tuvo como resultado paradójico su conversión de herramienta de análisis a bandera política, en el intento de hallar una ideología que cohesionara al grupo, y borrara al mismo tiempo las huellas de cultura religiosa que quedaban de la primera Açao Popular. La sustitución del foquismo por el maoísmo parecía una alternativa razonable para una organización de tradición movimientista con presencia entre trabajadores, estudiantes y campesinos, en un país donde, a pesar del veloz proceso de modernización iniciado en la era Vargas, hacia 1960 el índice de urbanización no pasaba del $45 \%$ de la población, y el paisaje social nordestino parecía alimentar el sueño del "cerco de las ciudades por el campo" ( $\mathrm{SCH}$ WARTZMAN, 1966, p. 366-388).

Del otro lado, el uso que hacía Montoneros del marxismo era instrumental, en un collage que de principio a fin se caracterizó por el eclecticismo ideológico, amoldando el peronismo combativo, el socialismo tercermundista, los teóricos asiáticos de la guerra revolucionaria y la teoría del foco. Los jóvenes montoneros que viajaron a Cuba, a diferencia del dirigente apista Paulo Stuart Wright y su frustrado intento por discutir textos marxistas, querían obtener capacitación militar y creían firmemente como los Tupamaros uruguayos que las palabras separaban a los revolucionarios, mientras los hechos los unían (BLIXEN, 2000, p. 77). En este sentido, no estaban buscando una 
identidad política, que ya consideraban portar por su asimilación al peronismo, ni tampoco valoraban la teoría revolucionaria como algo a priori de la práctica y las intuiciones de las masas. Como la clase obrera era nacionalista y peronista, el empirismo de Montoneros los llevó a adoptar una concepción etapista de la revolución, donde el peronismo como movimiento de liberación nacional era un primer paso hacia la instauración de una sociedad socialista. En otras palabras, lo que se nota como constante en la trayectoria de Montoneros es la primacía de la técnica sobre la teoría, ya que la lucha armada elevada al rango de estrategia para tomar el poder subordinaba a las demás formas de lucha, tanto en el período foquista (1970-1972) como en el ciclo abierto por la "ofensiva estratégica" (1975-1980). Si los dirigentes montoneros jamás dejaron de ver la acumulación de poder militar como la única válida (BASCHETTI, 1996, p. 279), las numerosas menciones a conceptos y frases de Mao no significaban una adhesión estrecha a sus principios, sino una adaptación a las necesidades discursivas del método de la lucha armada, sobre todo cuando el foquismo se volvió una término peyorativo para buena parte de la izquierda revolucionaria. A fin de cuentas, la adhesión al peronismo se correspondía con una sociedad argentina que contaba con una importante clase obrera urbana, mientras que la versión montonera de la guerra popular prolongada había requerido solo dos años de preparación sin un previo trabajo de masas.

\section{Consideraciones finales}

Açao Popular y Montoneros se forman por el cruce de procesos históricos originados en Europa y América Latina. En 1962, el papa Juan XXIII convocó al Concilio Vaticano II, para modernizar una institución que todavía se pensaba como una fortaleza asediada por la modernidad. La apertura conciliar en clave secular promovió las misas en lenguas nacionales, la celebración del rito de cara a los fieles, la opción preferencial por los pobres y el diálogo entre cristianos y marxistas, ya que el catolicismo quería ponerse al día con la revolución cultural de los años 60' para no perder su gravitación política, social y cultural. En el marco de la guerra fría y el avance de las revoluciones 
socialistas en el Tercer Mundo, la Iglesia hizo pública su preocupación por las consecuencias del desarrollo en las capas más empobrecidas de la sociedad, e intervino activamente en el debate en torno a la salud reproductiva, los cambios en la sexualidad y la cultura juvenil.

Sin embargo, la radicalización ideológica del catolicismo postconciliar no puede verse unilateralmente como resultado de una evolución interna de la Iglesia. El giro a la izquierda de varios católicos fue el resultado no esperado de la adaptación de las instituciones religiosas a los cambios sociales y culturales de los ańos 60. Como se argumentó más arriba, la radicalización de una parte de las capas medias y obrera fracturó y dividió a las juventudes laicas y sacerdotales. En la actitud de "ir al pueblo" con vocación misional con la idea inicial de cristianizar a una sociedad que parecía aleajarse de lo religioso, los militantes católicos rompieron con la Iglesia para construir sus propias organizaciones políticas, identificadas con la izquierda nacionalista, antiimperialista y socialista. Para comprender esta convergencia entre los católicos y las ideas de izquierda se debe tener en cuenta el surgimiento del Tercer Mundo como identidad política y cultural. El tercermundismo fue un movimiento de países no alineados con Estados Unidos ni con la URSS, capaz de colocar a Cuba, China, Argelia y Vietnam en un mapa unitario de la revolución mundial. El progreso de los conflictos sociales en América Latina, con la Revolución Cubana como punto de quiebre, radicalizó a los curas obreros, villeros o favelados, y a las agrupaciones estudiantiles católicas volcadas al trabajo social. Uno de los modelos de compromiso político más importante para los radicales católicos de los ańos 60 fue el sacerdote colombiano Camilo Torres, un egresado de la prestigiosa universidad católica de Lovaina que fue perseguido por su actividad política y se unió a la guerrilla del Ejército de Liberación Nacional, muriendo en combate hacia 1966. Parecía que las dictaduras de seguridad nacional solo dejaban el camino de la lucha armada, y un sector del catolicismo considero seriamente esa vía para terminar con el "pecado estructural" del capitalismo. Incluso la encíclica Poppulorum progressio del papa Paulo VI (1967) tenía una postura ambigua sobre la violencia ya que la condenaba, pero al mismo tiempo consideraba legítima la insurrección popular en casos de "tiranía evidente y prolongada". 
Como hemos visto, Açao Popular y Montoneros surgieron en el ambiente del catolicismo postconciliar, pero tomaron rumbos separados a partir de un menú de opciones políticas con mayor peso del populismo en la Argentina que en Brasil, donde la izquierda apareció como la única alternativa opositora a la dictadura militar. Al mismo tiempo, las orientaciones políticas que tomaron ambas organizaciones estaba condicionado por factores estructurales de orden socioeconómico, pero también coyunturales. Asumiendo el riesgo de caer en la historia contrafáctica y aceptando las posibilidades del "retorno del acontecimiento" en la historiografía contemporánea, vale preguntarse que habría pasado con Açao Popular si el atentado de 1966 en el aeropuerto de Recife hubiera concluido con la muerte de Costa e Silva. ¿Las tesis foquistas se habrian asumido como la línea correcta, transformando a AP en una organización armada? ¿La dictadura militar brasileña habría profundizado la política de terror en lugar de implementarla gradual y selectivamente? Lo mismo puede decirse del secuestro del general Aramburu por parte de Montoneros en 1970, cuyo impacto aceleró los tiempos de la guerrilla urbana en la Argentina. Para explicar la configuación histórica de una cultura política no habría que descartar nada, ni siquiera el papel del azar.

A pesar de las diferencias entre Açao Popular y Montoneros, también se puede pensar que las dos agrupaciones, en un determinado momento de desarrollo que coincide con sus primeros cinco años de existencia, buscaron una homogeneización político-cultural de sus cuadros y se orientaron a la construcción de un partido formalmente concebido como marxista-leninista. El proceso que inició Açao Popular en 1967 y Montoneros en 1975 tenía como denominador común la necesidad de uniformizar una militancia que atravesaba diversas tensiones internas, entre foquistas y movimientistas en Açao Popular, o las que habían provocado la secesión de la Juventud Peronista Lealtad en Montoneros. Por otro lado, los sendos contextos de creciente polarización política y endurecimiento de la represión también contribuyeron al disciplinamiento interno en ambas organizaciones, con el accionar de la Triple A en la Argentina y la promulgación del Ato Institucional n. 5 en Brasil como telón de fondo. Las coincidencias entre Açao Popular y Montoneros, sobre todo después de su apropiación más o menos libre del "marxismo-leninismo", 
también eran de orden programático, compartiendo por momentos las definiciones sobre la contradicción principal entre imperialismo y nación, o categorizaciones híbridas basadas en conceptos como clase y pueblo. Por extraño que parezca, ambos grupos germinaron en la misma matriz cultural, se diferenciaron notablemente en su desarrollo pero dieron sus últimos pasos en una dirección similar, por supuesto si sacamos de la ecuación el diferente valor que cada uno le daba a la lucha armada y al populismo. Los contrastes, sin embargo, son los que abren más preguntas para proseguir la comparación entre organizaciones revolucionarias, culturas políticas y formaciones sociales: ¿Qué mutaciones sufrió la caracterización de la lucha armada y la revolución en la breve historia de Montoneros y Açao Popular? ¿Por qué Montoneros privilegió lo técnico de las acciones armadas y Açao Popular se preocupó tanto por las definiciones teóricas de la línea política? ¿Era algo que tenía que ver con una diferencia en sus matrices católicas, con las bifurcaciones en la trayectoria de las dos organizaciones, o con otros factores? ¿Cómo se explica el hallazgo de puntos programáticos comunes, incubados en culturas políticas diferentes? Son preguntas que solo podrán empezar a responderse en el futuro a partir de nuevas investigaciones.

\section{CHRISTIANS, MAOISTS AND PERONISTS. ELEMENTS FOR A COMPARATIVE HISTORY OF AÇAO POPULAR IN BRAZIL AND MONTONEROS IN ARGENTINA}

Abstract: The purpose of this paper is to analyze the political militancy of Açao Popular and Montoneros, from the comparative method proposed by Marc Bloch in his classic article "For a comparative history of European societies". Following this line of research, we study the paths of both organizations comparing its origins in the renewing Catholicism, his approach to socialist positions and the differentiation of their political choices, to the Peronism in Montoneros, and to Maoism in Açao Popular. From this approach we can raise hypothesis about the specificity of political process at national level, in particular the strength or weakness of leftist and populist political formations in both countries, as well as crossings and disagreements between the two traditions. It was investigate general bibliography on guerrilla warfare and left in Argentina and Brazil, as well as specific literature about Açao Popular, Montoneros, the question of political 
and religious radicalization and the method of comparative history. Furthermore, we analyze a series of documental sources of the two organizations.

Keywords: Açao Popular. Montoneros. Maoism. Peronism. Comparative Method.

\section{Notas}

${ }^{1}$ Durante su estadía en Cuba, Paulo Stuart Wright fue castigado con un día de prisión por indisciplina, a causa de su insistencia en debatir textos marxistas (FILGUEIRAS, 2014, p. 330, p. 438).

${ }^{2}$ La doctrina de la guerra popular fue desarrollada por Mao para pensar la revolución en el contexto del conflicto chino-japonés. Lo popular estaba dado por el trabajo de masas requerido para formar guerrillas rurales y cercar la ciudad por el campo. Lo prolongado de la lucha se descontaba por la disparidad de fuerzas entre un país semicolonial y una potencia imperialista (TSE-TUNG, 1976, p. 113-200). 3 Para la Corriente 2, "[...] a revolução não é colocada como uma necessidade do caráter insustentável de uma estrutura, mas como decorrência de "injustiça”" (FILGUEIRAS, 2014, p. 528, p. 532-533).

${ }^{4}$ El nombre Montoneros provenía de los gauchos que peleaban "en montón", integrando las milicias rurales del federalismo provincial exaltadas por la historiografía revisionista, que en la primera mitad del siglo XIX combatieron a la facción liberal-unitaria de la ciudad de Buenos Aires.

5 “El llanto del enemigo", en Cristianismo y Revolución n. 28 (abril 1971), p. 72. ${ }^{6}$ Ibid.

7 "Hablan los montoneros", en Cristianismo y Revolución n.26 (noviembre-diciembre 1970), pág. 14. La definición del secuestro de Aramburu como un "foco peronista" aparece en el Boletín interno n. 1 de mayo de 1973 (BASCHETTI, 1996, p. 572). ${ }^{8}$ Una marca visible de la continuidad o ruptura con las prácticas y discursos del cristianismo liberacionista es que mientras Acción Popular mantuvo hasta 1965 formas de organización movimientistas heredadas de la JUC, como las coordinaciones estaduales y nacionales, las estructuras organizativas de Montoneros eran clandestinas y desde el principio trataron de imitar a los comandos de la resistencia peronista y la guerrilla guevarista.

\section{Referencías}

AARÃO REIS, Daniel. A revolução faltou ao encontro. Os comunistas en Brasil. São Paulo: Brasiliense, 1990.

Anos 90, Porto Alegre, v. 23, n. 43, p. 93-127, jul. 2016 
Cristianos, maoístas, y peronistas.

AARÃO REIS, Daniel; FERREIRA DE SÁ, Jair. Imagens da revoluçâo. Documentos politicos das organizaçôes clandestinas de esquerda dos anos 1961-1971. Rio de Janeiro: Marco Zero, 1985.

BASCHETTI, Roberto. Documentos 1973-1976. vol. 1. De Cámpora a la ruptura. Buenos Aires: Campana de palo, 1996.

Documentos 1970-1973. vol. 1. De la guerrilla peronista al gobierno popular. Buenos Aires: Campana de palo, 2004.

BENEDITO DIAS, Reginaldo. "A historia da Açao Popular na perspectiva do PcdoB: uma análise da obra de Haroldo Lima e Aldo Arantes sobre a história da AP”. In. Diálogos. v. 10, n. 1 Universidade Estadual de Maringá, Brasil, 2006, p. $143-175$.

BLIXEN, Samuel. Sendic. Acción y legado. Montevideo: Trilce, 2000.

BLOCH, Marc. "Pour une histoire comparée des sociétés européennes". In. Revue de synthèse historique. v. 46, p. 15-50 (p. 19), 1928.

CAMPOS, Esteban. Una teología para el Tercer Mundo. Mesianismo, historicismo y modernidad en Cristianismo y Revolución. In. Historia, voces y memoria. n. 2, 2010, p. 79-107.

D’ASSUNÇÃO BARROS, José. Origens da História Comparada. As experiências com o comparativismo histórico entre o século XVIII e a primeira metade do século XX. Anos 90. Porto Alegre, v. 14, n. 25, p. 141-173, 2007.

DEVOTO, Fernando; FAUSTO, Boris. Argentina-Brasil, 1850-2000. Un ensayo de historia comparada. Buenos Aires: Sudamericana, 2008.

FILGUEIRAS, Otto. Revolucionários sem rosto. Uma história da Açao Popular. São Paulo: Instituto Caio Prado Jr., 2014

GILLESPIE, Richard. Montoneros. Soldados de Perón. Buenos Aires: Grijalbo, 1989.

GORENDER, Jacob. Combate nas trevas. São Paulo: Fundação Perseu Abramo, 2014.

LANUSSE, Lucas. Caer y volver a levantarse. La situación de Montoneros entre fines de 1970 y comienzos de 1972. Jornada académica de Partidos Armados en la Argentina de los 70, UNSAM, 2007.

LOWY, Lowy. Guerra de dioses. Religión y politica en América Latina. México: Siglo XXI, 1999.

MARGARIA, Paulo. La fe no es una ideología y la ideología no es una fe. Entrevista a Frei Betto. In. Nuevo Mundo Mundos Nuevos (marzo de 2012). Disponible en: https://nuevomundo.revues.org/62990. Consulta en: marzo de 2015. 


\section{Esteban Javier Campos}

MONIZ BANDEIRA, Luiz Alberto. Brasil como un Poder Regional y sus relaciones con los Estados Unidos. Espaço Acadêmico. n. 62, julio 2006.

MORELLO, Gustavo. Cristianismo y Revolución. Los origenes intelectuales de la guerrilla en Argentina. Córdoba: EDUCC, 2003.

RIDENTI, Marcelo. Ação Popular: cristianismo e marxismo. In. AARÃO REIS, Daniel; RIDENTI, Marcelo (Org.). História do marxismo no Brasil, 5. Partidos e organizaçôes dos anos 20 aos 60. Campinas: UNICAMP, 2002, p. 213-282.

SALAS, Ernesto. El errático rumbo de la vanguardia montonera. In. Lucha armada en la Argentina. n. 8, 2007, p. 32-40.

SALAS, Ernesto. Del foco a la infección. Montoneros y los movimientos sociales. In. III Jornadas de Partidos armados en la Argentina de los 70, UNSAM, 2009.

SCWARTZMAN, Simon. Urbanización y desarrollo en Brasil. In. HARDOY, Jorge Enrique; TOBAR, Carlos. La urbanización en América Latina. Buenos Aires: Editorial del Instituto, 1966. p. 363-388.

TSÉ-TUNG, Mao. Sobre la guerra prolongada. In. Obras escogidas. tomo II. Pekín: Ediciones en Lenguas Extranjeras, 1976, p. 113-200.

. Sobre la práctica. In. Obras escogidas. Pekín: Ediciones en Lenguas Extranjeras, 1968, p. 318-332.

VALENTINI, Enzo Emiliano. Evolución económica comparada entre Brasil y Argentina: 1900-2010. Mendoza: Universidad Nacional de Cuyo, Facultad de Ciencias Económicas, 2012.

Recebido em: 20/ 10/ 2015

Aprovado em: 25/ 02/ 2016 